\title{
The Devil in Our DNA: A Brief History of Eugenics in Science Fiction Films
}

David A. Kirby

The publication of Charles Darwin's Origin of Species in 1859 challenged humanity's notion of divine creation and separation from the animal world by claiming that human beings are animals with an evolutionary link to all life on earth. For many people, this linkage to the animal world provided a scientific explanation for humanity's "immorality." Human beings could no longer consider immoral traits to represent punishment from God or temptation from the Devil. Instead, Darwin provided a natural explanation that these traits were our evolutionary inheritance. Darwin's cousin, Francis Galton, took this explanation further and concluded that most of society's ills, such as a propensity for violence and promiscuity, resulted from inherited animalistic behaviors. As natural rather than divinely-given traits, they should be correctable in future generations. In 1883, Galton proposed a system of selective breeding for human beings, which he termed "eugenics," that he believed could eradicate our bestial inheritance and ameliorate the social problems it created.

While Galton's ideas have consistently appealed to scientists and social reformers over the last 120 years, eugenics has been hindered by a lack of knowledge about our heritable material and a limited technological capacity for manipulating human heredity. ${ }^{1}$ However, developments in genomics, genetic engineering, and reproductive biology in the 1980s and 1990s have placed the eugenic goal of correcting and perfecting the human genome within our reach. As the technology develops further, many contemporary scientists and social commentators are now beginning to publicly champion eugenics as a legitimate social and scientific pursuit. In his influential book, Redesigning Humans, for example, Gregory Stock comes to the technologically deterministic conclusion that for genomic enhancement, "The question is no longer 
whether we will manipulate embryos, but when, where, and how."2 It is clear that, while the term "eugenics" may conjure up images as radically different as "better baby contests" and Nazi plans for a "master race," scholars such as Stock have moved eugenics as a desirable scientific and social goal from the edges back into the mainstream.

Not surprisingly, the recent social and scientific resurrection of eugenics has been accompanied by a spate of science fiction films addressing the ethical issues and ideological underpinnings of a eugenics movement based on emerging genomic enhancement technologies. ${ }^{3}$ However, as I will show in this essay, eugenic themes have been a constant presence in fictional cinema throughout the roughly hundredyear history shared by both eugenics and the cinema. In general, science fiction films provide scholars a gauge of social concerns, social attitudes, and social change regarding science and technology. The cornerstone of negative eugenics, that human beings retain animalistic behaviors from their evolutionary past, has been a prominent theme and visual motif in science fiction cinema. The key principle of positive eugenics, a belief that human beings have untapped evolutionary potential, has also been a staple element in numerous science fiction films. The persistence of these two themes in cinema over time reflects fundamental societal beliefs about heredity's role as the source of social problems.

Whether human beings are inherently criminal and violent or are one step away from Homo superior, eugenic goals are always about improvement. For eugenics proponents, the scientific search for heritable material was about finding a means for creating their conception of humanity. Therefore, eugenic themes in film also speak to our desire to control those biological elements that make us human. Both the "flawed humanity" and the "evolutionary potential" themes are frequently accompanied by a secondary eugenic theme of scientist characters attempting to manipulate human heredity in order to ameliorate social problems or to create superhumans. Ultimately, these films almost uniformly support the idea that humanity's fundamental nature lies within its genome and could be improved by technological means. However, these same films critique any attempts to manipulate human heredity. Most science fiction films thus accept the idea that perfection is possible, but critique the idea that "perfection" is desirable through technological means. In early science fiction cinema, perfection equals monstrosity, while later films question the notion that the perfect genome will actually lead to the perfect person. At the same time, because these films attribute spiritual significance to the human genome as well as position it as the locus of personal identity, they condemn any belief that our genome should be modified. 
The persistence of these themes over the last hundred years provides evidence that our beliefs and concerns about eugenic thinking, as represented in film, remain the same in the post-Human Genome Project age as they were in Galton's time. The only factors that have changed over the last hundred years are an increase in our knowledge of human heredity and our technological capacity both biologically and cinematically. We retain the same conviction that our fate is in our genome and the same hesitation about changing this sacred entity. With each new scientific discovery about the nature of human heredity, filmmakers have dusted off these themes and dressed them up with new graphical technologies.

Ultimately, I argue that attacks on the idea of biologically-directed human evolution find their strongest voice in science fiction films. Cinema has the ability to give tangible form to scientists' visions of a better humanity. Filmmakers portray for the public what is essentially a debate over an abstract entity, the nature of human heredity. Filmmakers also create concrete representations of our concerns about manipulating human heredity by depicting eugenic experiments gone awry. Transformation is at the heart of cinematic storytelling. For filmmakers, transformation is both visually interesting and makes for a compelling story. Eugenics is all about transformation: transforming human "animals" into the ideal human species or transforming human beings into "gods." Eugenics makes for good cinema, whether we want these transformations to happen or not.

\section{Human Apes and Soulless Monsters (1900-1929)}

The period between 1900 and 1929 represents the heyday of eugenics as a popular social movement. As medical historian Martin Pernick shows, cinema served as a battleground for pro- and anti-eugenic ideas. ${ }^{4}$ Several film genres, including drama, comedy, and romance, directly incorporated eugenics within their plots. Science fiction films of this period integrated eugenics more covertly, but more visually, by exploring humanity's connection to its bestial past and its spiritual fears of tampering with human heredity.

The idea that human beings retained bestial characteristics from their animal ancestors, a core concept in eugenics thinking, was a staple of early science fiction films. ${ }^{5}$ While these films feature a variety of plots for transforming apes into human beings or human beings into apes, the core notion established with these visuals is the direct link 
between humanity and "lower" animals. The unambiguous point of films like Darwin Was Right (1924) is that Darwin was right. From the filmmaker's perspective not only have human beings evolved from apes, they still are apes. The depictions of transformations from ape to human or human to ape made this connection explicit. In The Miser's Conversion (1914), for example, an old man is obsessed with Darwin's theory of evolution. The old man's physical appearance, stooped with a long white beard and bald skull, conjures up images of an aging Charles Darwin or, more appropriately, newspaper caricatures of Darwin with his bearded bald head superimposed on a monkey's body. The old man exchanges his daughter for a rejuvenation serum. After taking a few drops, he loses his wrinkles and reverts to forty years of age. Later he drinks the entire bottle and regresses into an ape. The miser's willingness to trade his daughter for a youth formula illustrates his apishness even before his regression visually proves this connection.

Several other science fiction films not only highlight the bestial nature of humanity but also depict the struggle to keep it under control or to remove it. There were a considerable number of film adaptations of Robert Louis Stevenson's 1886 novel The Strange Case of Dr. Jekyll and Mr. Hyde in this period, including one entitled The Duality of Man (1910). These films maintain Stevenson's "de-evolution" and degeneracy theme and feature scientific attempts to separate good from evil in the human mind. In the 1920 version, John Barrymore's critically lauded portrayal of Jekyll's transformation from human to the pre-human, ape-like Hyde, graphically endorses eugenicists' humanity/ape connection. As with the previous human/ape transformation films, the depiction of Jekyll's conversion into Hyde underscores the point that even a good man like Henry Jekyll harbors an animal nature that is ready to emerge at any time. Mr. Hyde's features are clearly more simian than human with his sloping forehead, wide nose, dark skin, hunched-over posture, sharpened teeth, and hirsute appearance. These physical characteristics are also in line with the stereotypically exaggerated features eugenicists commonly associated with "inferior races" such as Eastern Europeans and Africans.

Dr. Jekyll and Mr. Hyde was not the only book whose early film adaptations incorporated eugenic themes. The first two adaptations of Mary Shelley's Frankenstein are of interest because they stray from the novel by featuring a Dr. Frankenstein whose eugenics-based motive is to use science to create the perfect human rather than to defeat death. In Thomas Edison's liberal adaptation of Frankenstein (1910), the doctor uses alchemy in an attempt to create the perfect human being. When 
Frankenstein looks into a mirror near the end of the film, he does not see his normal reflection but that of the monster. Instead of creating the perfect being, the monster is literally portrayed as a reflection of Frankenstein's baser instincts and a dark reflection of a mind that presumed to meddle in God's domain. In the Frankenstein adaptation Life Without a Soul (1916), a scientist's attempts to create an invincible "New Breed of Man" fails miserably because his "perfect" individual is created without a soul.

The film serial Homunculus (1916) also features the creation of a perfect individual who is marred by the absence of a soul. The ape-like appearances of Mr. Hyde and Frankenstein's monster are unambiguous visual cues that humanity still retains many bestial traits. Homunculus's monstrosity, however, is not conveyed through a hideous outward appearance. Homunculus is handsome, well-dressed, and elegant, an austere exterior symbolizing his lack of a soul. He is the perfect creation, but as a being of cold, pure intellect without emotion or morality, his perfection is the perfection of science. Homunculus, then, is an exaggeration of eugenic desires: a physically and intellectually perfect individual whose perfection robs him of his connection to the rest of humanity.

The lack of a soul in these films anticipates what has become a common fear associated with human cloning. Generally, this concern centers on the uniqueness of both the genome and the soul. Opponents of cloning fear that because clones do not have unique genomes, they will not have unique souls. In the case of Homunculus and Frankenstein's monster, it is the act of technological creation itself that renders the individual soulless. More importantly, it is their knowledge that another person tried to "play God" by supplanting normal procreation, which turns these creations into monsters who seek out their "fathers" for revenge. As I argue later in this essay, the impact of genomic manipulation on the lab-designed individual resurfaces more forcefully in genetic modification films of the 1990s and 2000s. In these earlier films, however, the anxiety is not over the "soul" of the modified individual but rather the impact on the altered individual's authenticity.

Most of these early films support the notion that humanity was struggling with its animal nature. Even those films which challenge the concept of biologically altering human nature endorse the supposition that human beings need changing and that both personal and social problems can be traced back to heredity. Many of these films emerge out of, or appear recently after, World War I. During and after the war, eugenicists claimed that the war's carnage was the result of our 
inborn tendency to violence. ${ }^{6}$ For many people, the validity of this claim was borne out by the horrors they saw on the battlefield. Therefore, it is not surprising that many films uncritically accept the eugenicist's conception of humanity's tainted animal heritage. On the other hand, these same films served up visual warnings that any attempt to alter human nature is doomed to fail, or worse, to create soulless monsters as in Frankenstein, Homunculus, and Dr. Jekyll and Mr. Hyde. Even the scientists in the ape/human transformation comedies of the 1910s and 1920s were punished when they strove to master their inheritance.

The Mark of the Beast and Nazi Supermen (1930-1949)

Despite the decline of an organized mainstream eugenics movement, many people still felt that it was a moral imperative to improve humanity's genetic stock. Since discoveries in genetics and theoretical work in population genetics showed selective breeding to be flawed, scientists who still wished to improve the genetic makeup of humanity, reform eugenicists, needed to develop technological means to help human beings evolve to a higher state. ${ }^{7}$ By the late 1920s, Julian Huxley, H.J. Muller, and other reform eugenicists alleged that the best way to overcome biological and social problems was to directly manipulate humanity's genetic material. The idea of direct genetic manipulation began with a 1923 lecture given by evolutionary geneticist J.B.S. Haldane entitled "Daedalus, or Science and the Future." 8 "Daedalus" offered the vision of a eugenics program that relied on technological breakthroughs and avoided selective breeding.

The first official film adaptation of H.G. Wells's 1896 novel The Island of Dr. Moreau, Paramount Studios' The Island of Lost Souls (1933), was produced at a time when society was starting to address the concept of direct genetic manipulation. ${ }^{9}$ For Paramount Pictures, Wells's story of a scientist punished for scientifically attempting to create the perfect human being, seemed an ideal means of capitalizing on societal fears of a technologically driven eugenics. The filmmakers even invited eugenics proponent Julian Huxley onto their set to get his endorsement of the scientific accuracy of their film. ${ }^{10}$ As the film was being released, Russian scientists announced plans to evolve a human being from an ape, which the studio was quick to promote in press releases. ${ }^{11}$

A key element in Wells's novel is the "mark of the beast," those behaviors and personality traits that humans have inherited from their animal ancestors. In The Island of Lost Souls, Moreau's creations, the 
Beast People, symbolize the mark of the beast. The Beast People are indeed horrific reminders of humanity's tainted animal origins. Their ability to walk on two legs, their human clothing, and their rudimentary speech are human-like, but their hairy features, fangs, and pointy ears betray their animal origins. The makeup was so horrific, in fact, that it, along with the vivisection and bestiality themes, contributed to the film being banned in Britain and parts of the United States. ${ }^{12}$ As with Dr. Jekyll and Mr. Hyde, there are clear racial overtones in the film's depictions of "unevolved" humans. The other characters constantly refer to the Beast People as "natives" of the island, and their dark skin and hairy, hulking bodies are consistent with the stereotypical features eugenicists associated with "inferior" African races. The fact that the major characters do not even notice that the Beast People are animal/human hybrids illustrates how little they thought of "natives" to begin with.

What differentiates The Island of Lost Souls from previous films detailing humanity's "animal nature" is the overt linking of the mark of the beast to our genetic makeup and Moreau's use of genetic engineering to achieve his eugenic objectives. Moreau's goal in this film, in fact, is to remove the mark of the beast from our "germplasm," an older term for our hereditary material, by re-evolving human beings. Significantly, this moves concerns about the vague notion of "heredity" onto a concrete, physical substance that can be subjected to technological manipulation. The Island of Lost Souls is certainly unique among films before the discovery of the double helix in its fusing of eugenic and genetic engineering themes. Moreau's white suit, Panama hat, and whip give him the appearance of being one part plantation owner and one part ringmaster, trying to corral humanity's bestial past into a form he sees as good. In one of the most chilling scenes in horror film history, Moreau's creations punish him for his eugenic transgressions by dragging him into the "House of Pain," where they use Moreau's own medical instruments to cut him to pieces.

Although humanity's link to its primate past, its mark of the beast, was a common theme in science fiction films prior to 1930, these films were science fiction comedies. Earlier films, such as Reversing Darwin's Theory (1908) or The Monkey Man (1908), clearly affirm the human/primate connection, while simultaneously poking fun at those who take Darwin's evolutionary claims seriously. After the highly publicized Scopes Monkey Trial in 1925, the context of the human/primate connection in science fiction films changed from comedy to horror. Several post-Scopes films, beginning with The Wizard in 1927, feature 
"mad evolutionist" characters who design evil experiments in order to prove their evolutionary theories about humanity's connection to the animal world. Likewise, the goal of the mad evolutionists in The Beast of Borneo (1934) and Dr. Renault's Secret (1942) is to prove humanity's link to the animal kingdom. Standing in front of a chart detailing the evolutionary "tree of life" along with a gorilla named Erik, the mad evolutionist Dr. Mirakle from Murders in the Rue Morgue (1932) informs an unbelieving carnival audience that "the shadow of Erik the ape hangs over us all" and that he will mix human and gorilla blood to "prove your kinship with the ape." While the evolutionary-minded scientist is ultimately punished for his heretical conceptions, the film actually conveys the human/ape connection through Mirakle's grotesque appearance and his clearly "animalistic" actions. In mad evolutionist films, the only human beings with a clear connections to primates are the evolution-spouting, evil scientists and their simian-like assistants.

By the end of the 1940s science fiction films no longer included the theme of the "mad evolutionist." While they continually employed the human/primate connection, usually through brain transplants, scientists in later films were no longer satisfied merely to prove human beings are animals. Nazi atrocities during the Second World War seemed to provide certainty to the eugenic conviction of humanity's bestial connection. That these acts were carried out in the name of eugenics is a great irony: although eugenicists could point to Nazi horrors as evidence of humanity's inherent flaws and the need for eugenic policies, their calls were muted by the fact that the Nazis had taken these same policies to extremes. By the 1940s, science fiction films included eugenics most overtly through Nazi-like mad scientists whose attempts to create super soldiers parodied Nazi eugenic plans for a master race, as in The Mad Monster (1942), The Boogie Man Will Get You (1942) and Revenge of the Zombies (1943). The mad scientist bent on producing the perfect human would continued to be a staple of science fiction cinema even into the 1990s, as in The Unborn (1991), but by 1950 two new scientific "characters" radically changed the nature of eugenic themes in science fiction cinema: radiation and the double helix.

Radiation, Our Genetic Future, and the Dawn of the Double Helix (1950-1969)

Film scholars routinely ignore genetics and DNA when discussing science fiction films of the 1950s. The wide variety of films in this 
period is generally distilled as reflecting concerns about three threats: the Cold War and communism, suburbanization and social conformity, and the atomic bomb and nuclear catastrophe. I have argued elsewhere that 1950's cinema represents a much more complex picture of society's relationship to science and technology, in particular genetics. ${ }^{13}$ The abstract concept of "genetic material" became a concrete and material reality with the resolution of the DNA double helix in 1953. DNA represented the ultimate in scientific materialism because it claimed that a single double helical molecule could explain the "secret of life." The discovery of DNA also fueled public fears that since scientists had access to this "secret" they would want to alter humanity. Science fiction filmmakers incorporated eugenic themes into both high profile and B-grade science fiction films.

Radiation and the threat of nuclear war added a new level of anxiety to eugenic-themed films. In these films, scientist characters not only saw eugenics as a means to ameliorate contemporary social conditions, they also asserted that humanity's very survival depended on its ability to manipulate human heredity. Popular media of the 1950s and 1960s were filled with dire warnings about the degradation of the human gene pool from continued atomic testing. ${ }^{14}$ Plots revolving around radioactive genetic degradation include Captive Women (1952), Terror from the Year 5,000 (1958), The Time Travelers (1964), Mars Needs Women (1966), and Blood Beast From Outer Space (1966). Most of these films symbolize our unprotected genetic future in the form of gruesomely mutated humanoid monsters. This theme, in fact, has played continually in science fiction films from the 1950s to 1989's Millennium. Several films of the 1950s and 1960s also show a eugenic concern for altering our DNA now, so that humanity can avoid disaster and survive a nuclear war with our genes intact. In The Werewolf (1956), the mad scientists' solution is to immunize humanity by exposing people to small amounts of serum made from a radioactive "mutant wolf." Interestingly, these scientists' eugenic methodology contradicts most eugenic thinking by moving humanity back toward its animal past.

In many science fiction films of this period, our inherited animal instincts are the reason we are on the brink of nuclear annihilation. In the genre classic Forbidden Planet (1956), for example, the "monsters from the id" are visual representations of humanity's repressed animalistic nature released by the machinery of the Krel, who were destroyed by their own unleashed baser instincts. Likewise, Planet of the Apes (1968) highlights humanity's un-evolved state by juxtaposing the qualities of the haughty, self-assured gorillas with the violent, arrogant 
astronaut Taylor whose human society ended in nuclear war. The apes also deny their own evolutionary past and appear to be on the same doomed trajectory as human beings. The plots of several low budget science fiction films, such as an unofficial adaptation of The Island of Dr. Moreau entitled Terror is a Man (1959) and I Was a Teenage Werewolf (1957) include the eugenic desire to re-evolve humanity in order to prevent us from destroying ourselves.

For eugenic-minded individuals, the understanding of DNA as the genetic material meant that scientists could "improve" human genes through directed mutations without the need for selective breeding, sterilization, or other extreme measures. Although the scientific community saw promise in the direct manipulation of DNA, most of the general public found the idea of directly manipulating humanity's hereditary material unpalatable and frightening. Science fiction films incorporate these concerns through scientist characters claiming to have discovered a hereditary molecule that explains the way we look, age, and behave and then proceeding to alter this molecule. In She Demons (1958), The Killer Shrews (1959), and Konga (1961) scientists discover a molecular entity resembling DNA before attempting to improve the human race by using this knowledge to make "directed mutations." The deformed she demons, the monstrous killer shrews, and the gigantic, mutant ape Konga each graphically symbolize these screen eugenicists' misguided desire to control human heredity in order to create a new race of humans.

In She Demons, mad eugenicist Colonel Karl Osler claims that the molecule "Character $X^{\prime \prime}$ is " . . . a chemical quality, composed of genes. That gives us our personal appearance, our individual character." Osler and his henchmen wear Nazi uniforms, a straightforward visual cue that his eugenic plans are pure evil. The filmmakers depict the transformative power of "Character $X$ " by showing us the results of Osler's eugenic experiments. Osler has been trying to create a master race by transferring Character $X$ from one person to another. Unfortunately, his eugenic plans have not worked out very well. A combination of Character $X$ from his disfigured wife, Mona, and animals does not create a master race but transforms some island women into hideously deformed "animal people." Character X from the island women, however, does not seem to have a lasting effect on Mona. In one of the film's most well-known scenes, Mona removes her bandages, revealing that her face is just a skull with two eyeballs. The over-the-top visuals of Mona's mutilated face clearly indicate that Osler's attempts at creating a master race have been a complete failure. 
Surprisingly few films of the 1960s include references to DNA, and even fewer feature human genetic manipulation. There were, in fact, hardly any eugenic-themed science fiction films in the 1960s. This is partially explained by a reduction in the production of science fiction films in the 1960s, but it also reflects a change in long held beliefs about the biological basis of social problems. Throughout the 1960s, the primacy of nature over nurture was reversed, and by the end of the decade, the belief that social environment was the larger contributor to societal problems like crime and poverty became entrenched doctrine. The social climate in the 1960s was not conducive to eugenic thinking, and science fiction films reflected this sociopolitical atmosphere.

\section{The Reality of a Genetically Engineered World (1970-1989)}

Rather than moving us closer to a eugenic utopia, advances in our knowledge of human genetics in the 1960s actually revealed further obstacles. Eugenics re-emerged as a social issue and a scientific endeavor following the advent of genetic engineering in the early 1970s. Medical historian Daniel Kevles argues that new gene technologies accompanied a renewed assertion among social commentators of biology's role in the cause of societal problems. ${ }^{15}$ For many social commentators, the search for a solution to deteriorating social conditions of the 1960s and 1970s started squarely with the need for human gene-altering technologies. Critics of the new technologies, on the other hand, began to use the phrase "new eugenics" to describe the possible application of these technologies to the human genome. Critics feared that governmental and scientific institutions would employ gene-altering technologies in a manner reminiscent of the social control embodied in an "old" eugenics reliance on selective breeding. Even after the advent of genetic engineering in 1973, however, few science fiction films incorporated the alteration of human DNA for eugenic purposes before the end of the 1970s.

The eugenics staple of humanity's inherited animal nature crops up again in films of the 1970s and 1980s. There are even striking similarities in these films to the ape/human regression films of the 1910s and 1920s. Several films depict the connection to primate ancestors through human "de-evolution" to an animal past, as in Altered States (1980) and the Italian produced Regenerator (1990). Likewise, a host of films portray the connection of human beings to primates by featuring monkeys with human intelligence, such as Link (1986), Monkey Shines 
(1988), and Primal Rage (1988). Unlike earlier films, these intelligent monkey films have as much to do with animal rights as they do with eugenics. While the human/ape connection is central, the point of these films is not just that human beings are animalistic but also that animals can be human and deserving of rights.

While radiation was humanity's greatest fear in the 1950s, concern shifts to environmental disintegration in the 1970s, at least as depicted in many low budget science fiction films. Films of this period feature scientists who aspire to evolve new species of human beings that can survive environmental catastrophe, such as the mad herpetologist film SSSSSSS (1973). Several of these films incorporate human genetic engineering as a means of protecting humanity from eco-disaster. The mad botanist in The Mutations (1974) creates human/plant DNA hybrids to protect humanity from population explosions and hunger. And, in the Island of Dr. Moreau inspired exploitation quickie, Screamers (1979), another mad herpetologist believes that the only way for human beings to survive an overpopulated world is to genetically de-evolve to an ancestral amphibian state. The horror in these films derives from the disparity between what the scientists believe they are doing, creating superhumans, and what actually appears on screen, the transformation of humans into monsters. Interestingly, while these films are part of the 1970s eco-catastrophe subgenre, they do not represent the genetically engineered organisms as an eco-disaster in their own right as in recombinant DNA films of this period. These cinematic scientists have the right priority, avoiding eco-disaster, but filmmakers clearly consider the solution of genetically modifying humanity to be worse than the original problem.

One element that uniquely emerges in science fiction films of the 1970 s and 1980s is the theme of a computer-enhanced humanity. If human evolution has stalled, it is suggested that we might overcome these limitations and achieve eugenic goals through cybernetic enhancement. In The Terminal Man (1974), for example, scientists try to control human violence not by evolving new human beings but by controlling violence itself through computer enhancement. Several films feature robots that represent, at least for characters in the film, the "perfect" person, including The Stepford Wives (1975), Making Mr. Right (1987), and Cherry 2000 (1988). These films differ from earlier artificial person films like Homunculus in that the characters they feature are not soulless creations that go on murderous rampages. Interestingly, the "perfect" cyborgs in these films are designed as sexual partners for human beings. One film combines DNA manipulation and robotics to evolve a 
better human. In Demon Seed (1977), the computer Proteus IV becomes the perfectly evolved creation using genetic engineering and artificial insemination to create a body for its "brain."

No other film explores the relationship between computers, genetic engineering, and a "new" humanity more than the 1982 film Blade Runner. In the film the Tyrell Corporation uses a combination of genetic engineering and robotics to create artificial beings called "replicants." Interestingly, the replicants are engineered to possess qualities that eugenicists appreciate-superior strength, agility, and intelligence-but humans consider replicants lesser beings and assign them tasks humanity does not want to do or cannot perform. The film raises issues about the nature of humanity by questioning whether the replicants, even though they are biologically manufactured, can be considered "human." In the end the replicants do not want to be considered "superior" to humanity, rather they want to be considered an equal part of humanity. As Donna Haraway, in Simians, Cyborgs, and Women: The Reinvention of Nature, contends, such "cyborg bodies" show how the boundary between organisms and machines has eroded to the point of invisibility. ${ }^{16}$

Not surprisingly the first films in the 1970s and 1980s whose scientists utilize genetic engineering in the service of human evolution are two film adaptations of The Island of Dr. Moreau. A 1972 adaptation, Twilight People, features a mad scientist who uses genetic engineering, along with brain transplants, in an attempt to replace a defective human species with a master race. The phrase "new eugenics" is meant to link genetic engineering with the images of Nazi scientists associated with the "old" eugenics. This linkage is made explicit in Twilight People when the hero tells the mad scientist, "I'm a little skeptical about building master races. Maybe it's the unsavory precedents."

In the 1977 official film adaptation of The Island of Dr. Moreau, Moreau removes the "mark of the beast" through genetic manipulation. ${ }^{17}$ The film is, in fact, a throwback to the DNA films of the late-1950s in which scientists discover DNA before conducting eugenic experiments. Moreau, who has written a book on eugenics and inheritance, is motivated by the notion that "there have been enormous advances in technology, but how much in Man?" He uses his newly-discovered hereditary material to put a "new set of instructions" into experimental subjects, which erases their animal instincts in order to create an improved version of humanity. The shipwreck victim, Braddock, exemplifies the "mark of the beast" in this film. As film scholar Barry Grant points out, the scene of Braddock living among the Beast People is 
a "vividly realized metaphor of the animalistic qualities within us."18 This metaphor is taken even further when Moreau "regresses" Braddock to an earlier, and animal, stage in human evolution. The filmmakers visually communicate the idea of the animal within humans by making Braddock as a regressed "humanimal" appear identical to when he is unshaven at the beginning of the film. As with 1950s cinematic scientists, while Moreau is able to manipulate heredity, his belief in technological control leads to his downfall.

The 1988 film Twins provides an atypical counter example to most science fiction films by noticeably rejecting the notion that our genome houses our fundamental nature. In the film, six distinguished men donate to a "sperm milkshake" used in a eugenic experiment to create the perfect man. Instead of one child, the experiment resulted in two children. All the "purity and strength" genes wound up in Julius, while all the "genetic garbage" went to his twin brother, Vincent. The visual play between the hulking Arnold Schwarzenegger (Julius) and the diminutive Danny DeVito (Vincent) is meant to graphically convey the idea that Julius has inherited the good genes and Vincent has inherited the bad genes. The film, however, directly attacks the eugenic notion that good genes make good people and bad genes make bad people. By the end, Julius, who sports a "Born to Be Bad" t-shirt, exhibits a violent streak and the supposedly evil Vincent ultimately saves Julius's life. The film clearly privileges nurture over nature, and climaxes when Julius tells Vincent that his loveless childhood environment, not his genes, made him bad.

Ultimately, the number of films in the 1970s and 1980s incorporating genetic engineering and eugenics is small compared to the number of films based on recombinant DNA experiments involving the DNA of two different species, such as Piranha (1978), Swamp Thing (1982), Leviathan (1988), and The Nest (1988). Even the overtly anti-eugenic Island of Dr. Moreau conflates concerns over human genetic manipulation with concerns for recombinant DNA technology. For science fiction films of the 1970s, recombinant DNA represented the greater technological threat. While the possibility of human gene manipulation and a new eugenics existed, recombinant DNA experiments were already a reality.

Liberal Eugenics, Genomic Enhancement, and the Mark of the Devil (1990-2004)

The paucity of human genetic engineering films quickly changed in the 1990s, after the successful application of human genetic engi- 
neering technologies. Advances in genomics, genetic engineering, and reproductive biology made the realization of eugenic goals possible. Molecular biologist Lee Silver sees this confluence of technologies as leading to a new category of technologies he refers to as "reprogenetics." ${ }^{19}$ Several scholars, such as bioethicist Nicholas Agar, have embraced the notion of genomic enhancement as a personal right and lobby for a "liberal eugenics." The current push for genetic enhancement is driven by a libertarian perspective coupled with parents' desire to provide their children with every possible advantage and the lobbying efforts of patient advocacy groups. ${ }^{20}$ Recent scientific accomplishments have brought human gene manipulation out of the realm of science fiction into reality, then back into science fiction as filmmakers grapple with the bioethical and social issues surrounding emergent technologies in films depicting our internal battles over the source of human nature.

In the film Code 46 (2003), the widespread application of in vitro fertilization, donor insemination, and cloning has led to a world where people no longer know to whom they might be genetically related. Any sexual encounter could lead to incestuous reproduction with the attendant concerns over the pairing of recessive mutations and increases in genetic disorders. The government's concerns over inbreeding's effects on the gene pool result in a draconian eugenic regulatory system where illicit pairings are severely punished; a system that would have been the envy of hard-line eugenicists of the 1920s. Rather than creating a more genomically pure world, reprogenetics in Code 46 has led to the type of social control associated with the old eugenics.

Even though the most common use of reprogenetics is to correct life-threatening genetic disorders, science fiction films rarely feature this as a plot element because it does not make for an action-packed narrative or have the potential for interesting visuals. One clear case of genetic intervention to cure a life-threatening genetic disorder in this period appears in the 1997 film Batman $\mathcal{E}$ Robin. In the film, we find that the villain Mr. Freeze is not motivated by money or power like other super villains in the series; his crime spree is in the service of finding a cure for his wife's rare genetic disorder, the fictional "MacGregor's Syndrome." Unlike films that grapple with genetic enhancements, Batman $\mathcal{E}$ Robin portrays genetic manipulation as a beneficial technology. When Batman's loyal butler, Alfred, begins to show symptoms of stageone MacGregor's Syndrome, Batman makes a deal with Mr. Freeze. In exchange for his cure to early-stage MacGregor's Syndrome, Mr. Freeze will have access to a lab and equipment while behind bars so that he can continue his search for a complete cure. 
The ultimate goal of reprogenetics is to cure every genetic disease, which would, as a result, effectively render humanity immortal. The notion of genetically engineered immortality crops up in two recent science fiction films. In these films the key to long life is not present in our own genome but in the genome of other species. A dog's genome harbors the secret of eternal life in the recent re-make The Shaggy Dog (2006). Scientists' attempt to harness this genetic potential by fusing dog genes with the human genome through viral vectorbased gene therapy. Unfortunately, as was the case in films of the 1970s and 1980s, this attempt merely creates hybrid monsters, such as a frog-dog and a snake-dog, as well as the central visual motif of human/dog transformation rather than an improved humanity. While manipulation of the human genome is not part of The Fountain (2006), genomic research and biological transformation play a central role in the film's immortality theme. Although his discovery is too late to save his wife from dying of cancer, an oncologist finds the "tree of life" whose genetic properties can cure humanity of all its genetic diseases. While not overly critical of biotechnology, the film concludes that biological death should not be tampered with. At the conclusion of the film the oncologist realizes that death adds significance to human existence and he ultimately chooses not to engage in the research.

While research into human gene manipulation focuses on correcting genetic disorders, there is a growing contingent, particularly among social conservatives, who place the blame for social ills squarely within our genome and envision these new technologies as a means of enacting social change. ${ }^{21}$ Several science fiction films of this period feature the most common eugenic theme in science fiction cinema by locating humanity's dark side in the genome. What is unique about its appearance is the explicit attribution of agency to the genome for social problems. Nelkin and Lindee, authors of The DNA Mystique, note Alien III's (1992) perpetuation of the myth of a link between criminality and an extra Y chromosome. ${ }^{22}$ Likewise, in 28 Days Later (2003), "rage" is identified as a biological entity that can be engineered and manipulated. Heather Schell, in her article in this issue, argues that Wolf (1994) and The Wolves of Wall Street (2002) promote a sociobiological notion that primitive male "aggressive" behaviors are deeply embedded in humanity's DNA.

In Godsend (2004) evil is not the product of social conditions but is deeply embedded within the human genome. In the film, a scientist produces a clone from the cells of a recently deceased child named Adam. Unbeknownst to Adam's parents, the scientist combines cloning 
with genomic modification by integrating some genetic material from his own dead son, Zachary. The film perpetuates the common myth that a cloned individual will retain memories from its donor genome, as the cloned Adam has visions from Zachary's viewpoint. It also furthers the notion that our personalities and behavioral traits are hard wired into our genome. We are told through the dialogue that the scientist was not only able to control the clone's "physical appearance" but he could also manipulate "intangibles," including cognition and personality. Most crucially, the film overtly connects antisocial behavior to genetics. At some point in the film the previously well-behaved Adam starts to exhibit criminal behavior, including murder. The film's entire premise rests upon the notion that this change in behavior is due to the presence of Zachary's genes. Although the film includes possible external explanations for Zachary's behavior, such as bullying and bad parenting, the film ultimately ignores these in favor of an innate evilness. This inborn evilness means that his resurrected DNA causes Adam to act out violently regardless of his nurturing home environment. In Godsend it is not the act of cloning itself that is immoral; cloning only becomes problematic when the technology is used to resurrect individuals whose genomes harbor evil genes.

The theme of a bestial humanity, whose inherent flaws put it on the path to global destruction, surfaces again in this period. Unlike films of the 1950s, films in the 1990s feature a more extreme version of this theme. In these films, human beings' genomic imperfections put them beyond eugenic reclamation, and the whole species must instead be exterminated. The plots of Carnosaur (1993), Twelve Monkeys (1995), and Sky Captain and the World of Tomorrow (2004) incorporate a scientist who believes that human beings are destroying the Earth, and the only way to prevent it is to eliminate humanity. In Species (1995), an alien race decides human beings are a "galactic weed" and sends a biological weapon to exterminate Homo sapiens. In these films, humanity's ability to manipulate genetics is not seen as a means of "curing" its problems; gene-altering technologies provide ways of wiping out a genomically-deficient human species.

Not every film with the "bestial human" theme in this period finds the human species beyond eugenic reclamation. The 1996 adaptation of The Island of Dr. Moreau features an overtly eugenic-minded Moreau who has "been striving to create some measure of refinement in the human species." The "mark of the beast" is illustrated visually by Moreau's eugenic creations, the Beast People. It is also conveyed by having the human characters act like animals and through the 
characters' direct references to humanity's animal nature. ${ }^{23}$ With his white muumuu, rosary-like beaded necklace, and domed "Popemobile," Moreau suggests the image of a eugenic high priest. Indeed, Moreau uses religious metaphors to describe how he thinks animalistic behaviors are humanity's genetic heritage: "The devil is that element in human nature that impels us to destroy and debase." Moreau, in fact, posits himself as more like a eugenicist God rather than a mere priest as he tells the shipwreck victim, Edward Douglas, about how he has defeated this genetic devil:

I have seen the devil in my microscope and I have chained him, and I suppose if to say in a sense metaphorically speaking, I have cut him to pieces. The devil, Mr. Douglas, I have found is nothing more than a tiresome collection of genes. It is with great assurance that I can tell you that Lucifer, son of mourning, is no more.

Even though Moreau feels he can save humanity from its genetic demons, the film makes it clear that the devil is embodied in a scientist's willingness to manipulate humanity's molecular soul.

Human beings are not the only species with eugenic plans in recent science fiction films. The plot of the 2002 sequel Blade II revolves around a vampire overlord's eugenic plan to create a "pure race" of vampires. In fact, the notion of a "pureblood" vampire runs throughout the films in the series. Mirroring an element of the old eugenics the aristocratic pureblood vampires feel that the influx of "immigrants," newly turned vampires, is leading to their degeneracy as a race. The overlord turns to genetic manipulation to remove genetic deficiencies from the vampires. Of course, vampiric genetic defects, susceptibility to silver and sunlight, differ from human genetic disorders, but like human eugenicists the overlord believes these defects are keeping down the "ascendancy of our race." The overlord's concerns mirror those of eugenicists from the heyday of the eugenics movement: race dilution and the desire for a pureblood master race. The overlord, however, employs gene-altering technologies rather than selective breeding to achieve his eugenic goals. The film underscores the evil nature of the overlord's eugenic activities through the fact that he uses his own son in the genetic experiments. Eugenics, it seems, is a clear-cut means of making vampires more evil. By implication, the film condemns any person utilizing gene-altering technologies to achieve social control. This plot point conjures up fears associated with the old eugenics and reinscribes the notion of social control combined with genetic engineering 
that formed the basis of anxieties over a new eugenics in the 1970s and 1980s. These concerns, however, ignore the consumer-driven nature of the liberal eugenics movement of the 1990s and 2000s.

Although it does not involve reprogenetics, the X-Men films contain several eugenics-based themes. Although they are created through natural mutation and not genetic engineering, the films imply that the "mutants" represent the eugenicists' goal of a more highly evolved human species. The voiceover opening of X-Men (2000), which also ends $X 2$ (2003), would not seem out of place in the writings of staunch eugenic scientists like H.J. Muller and Julian Huxley: "Mutation. It is the key to our evolution. It is how we have evolved from single celled organisms into the dominant species on the planet. This process is slow. Normally taking thousands of years." According to eugenicists this is exactly why we need to accelerate the evolutionary process. The rest of humanity, however, is not sure the mutants represent a superior genome. They, in fact, consider the mutants to be an inferior, and dangerous, new species.

This fear of perceived genetically inferior groups plays out in the first $X-M e n$ as akin to eugenics driven American anti-immigration legislation in the 1920s. Eugenicists of the 1920s were worried that immigrants from Eastern and Southern Europe were diluting America's gene pool, and they successfully lobbied for federal legislation to restrict immigration. The film hearkens back to these legislative battles with its "mutant registration act" storyline. In addition, the film's anti-mutant meetings symbolically take place on Ellis Island with the film's climactic showdown taking place on top of the Statue of Liberty. In X-Men, mutants are a new class of immigrants whose dangerous genome threatens the American public. The theme of genetic impurity runs throughout the X-Men films. The third film, X-Men: The Last Stand (2006), takes the eugenics theme to its ultimate conclusion as genetic engineering emerges as the means by which non-mutants finally manage to purify the mutant genome. This genetic "cure" represents a common fear of genetic modification: that those in power ultimately determine what represents the "correct" genome.

While some mutants rebel against their genome and take this genetic cure in the third film, several mutant characters believe from the beginning that it is the non-mutants who need to improve their genome. Just like the vampire overlord in Blade II, the leader of the "Brotherhood of Mutants," Magneto, is certain that his species is genetically superior to Homo sapiens. As Magneto tells another mutant in X2, "You are a God among insects. Never let anyone tell you differently." 
This theme of racial purity is ironic coming from Magneto, who as a Holocaust survivor was directly impacted by Nazi racial polices. Unlike the vampire overlord, Magneto does not attempt to elevate the genome of his own species, but instead works to change the genomics of "lesser" humans. Positive eugenics forms the premise of X-Men as Magneto creates a machine that will genetically modify humans into mutants. In X2 Magneto takes an extreme negative eugenics approach to genetic purification, one akin to the Nazi "final solution," by attempting to kill every non-mutant on the planet.

Most contemporary eugenic-minded individuals focus less on using biotechnology to correct social problems and more on the prospect of genomic enhancement. A significant number of films in this period include the eugenic theme of humanity's untapped evolutionary potential. A popular theme in the 1940s, the genetically-enhanced super soldier is also a prevailing theme in science fiction films of the 1990s and 2000s. Most often, films depict the military or government as the institution taking advantage of untapped potential in order to create super soldiers, including Universal Soldier (1992), Judge Dredd (1995), and Soldier (1998). What is meant to be a transformation from man to superman is often graphically portrayed in these films as a genetic change from man to monster as in Hollow Man (2000), Spiderman (2002), Hulk (2003), and Resident Evil: Apocalypse (2004).

In films of the 1910s and 1920s, technological interference in reproduction reflected religious concerns about tampering with God's domain. Recent science fiction films reflect the rise of an individualistic identity culture in the $1980 \mathrm{~s}$ and $1990 \mathrm{~s}^{24}$ These films suggest that identity resides in genes and that technological attempts to alter the genome will fundamentally change authenticity. ${ }^{25}$ In Blade (1998), we learn that vampirism is a "genetic defect, just like hemolytic anemia," which Blade inherits when his pregnant mother is bitten by a vampire. The only way to treat this disorder, according to the hematologist in the film, is through a gene therapy that overwrites the victim's DNA with the "retrovirus . . . they've been using to treat sickle cell anemia." It is hard to ignore the racial overtones of having an African-American geneticist comparing sickle cell anemia to the vampirism of the African-American Blade, who was born with the vampiric disorder and refuses treatment, believing that changing his genomic distinctiveness will change his personal identity.

While the genetic defect in Blade is clearly detrimental, at least for human beings, the genetic changes in The Nutty Professor (1996) straddle the line between treatment of a genetic disorder and genetic 
enhancement. In the film, the hyper-obese Klump alters his genome and in the process becomes the slender "Buddy Love." In keeping with the anti-eugenic themes of past science fiction films, The Nutty Professor implies that any change to the human genome is an intrusion into God's realm. Rather than producing a better version of himself, Klump's genetic manipulation unleashes the testosterone-overloaded Buddy Love, reminiscent of an earlier Mr. Hyde in his behavior. Even though Klump corrects genetic hyper-obesity, his mother makes the case against such enhancements, saying that Klump must accept that "the good Lord . . . made you beautiful." Despite his interference with the Lord's handiwork, Klump is not punished on moral grounds. In recent science fiction films, tampering with a character's genome does not create a "soulless" monster as it did in early films; instead these interventions lead to a character's search for authenticity.

Among recent science fiction films, one film stands out as a throwback to the early serious-minded eugenic films analyzed by Martin Pernick. ${ }^{26}$ GATTACA (1997) depicts a future world in which parents are encouraged to perfect their offspring's genome before birth. ${ }^{27}$ Not everyone has access to the technology in this near-future world, and society discriminates against individuals who have not been genetically enhanced. GATTACA depicts many of the ethical issues associated with the new eugenics, such as genetic discrimination, genetic prophecy, and the homogenization of society. Genetic discrimination is made visible through shots of gates and doors closing on the genetically unmodified Vincent. Other scenes literally depict the new "glass ceiling" that exists when genetic discrimination is illegal but openly practiced as Vincent constantly presses his face against windows and looks up through a skylight at the Gattaca Corporation. These glass barriers materialize the predicament faced by Vincent, who should legally be able to work on the inside but is shut out due to the discriminatory practices of GATTACA's society.

Other visual motifs express the overriding belief in genetic prophecy within GATTACA's society. Mimicking a DNA sequence, the title of the film itself is composed of the four DNA bases, Adenine, Guanine, Thymine, and Cytosine. In the same manner, the awardwinning opening credits show individual names with $A, G, T$, and $C$ highlighted (e.g., GORE VIDAL); after two seconds, the other letters fade away and only the highlighted letters remain. This highlighting technique establishes, at the very outset of the film, that the genetic code is considered more powerful than other letters and elements. The image of DNA is also seen in the double-helical design of the staircase 
in Eugene's apartment. Eugene, who is paralyzed after an attempted suicide, is constantly reminded that he is unable to climb the DNA staircase to the upper floors. Both the wheelchair and the DNA staircase symbolize Eugene's inability to live up to his perfect genetic makeup, and Vincent's ability to transcend his imperfect genome.

In GATTACA, body matter serves as a visual metaphor for a person's genetic identity. Blood, skin, hair, eyelashes, urine, and saliva are all used in the film to collect genetic readouts on various characters. Of all the body matter depicted in the film, blood provides the dominant metaphor for the importance of genetics in GATTACA's society. There are eight extreme close-ups of blood droplets in the film, not including other important shots of blood in storage bags or covering the face of a murder victim. Penetrating to the core of what defines humanity in GATTACA, these extreme close-ups of body parts and waste matter are extremely alienating, suggesting that human beings are valued less than their cast-off DNA. Visually, GATTACA also conveys the cost of "perfection" with an antiseptic world that has been purged of imperfection and blemish. The Academy Award-nominated sets show a sterile and blemish-free world filled with smooth, stainless steel surfaces. The costuming in GATTACA also suggests homogeneity and uniformity, with all the employees of the corporation, men and women alike, wearing matching black suits.

Unlike other science fiction films of this period, such as The Island of Dr. Moreau, that critique human genome manipulation, GATTACA maintains that any ethical issues with human genetic engineering will not result from the technology itself or the whims of scientists. GATTACA posits that ethical problems will only arise if the genetic determinist belief that individuals are no more than the sum of their genes becomes an accepted ideology. GATTACA's overt message is that we are more than the sum of our genes and that being human means we are able to "transcend" our genetic obstacles. Like eugenics films of the past, GATTACA accepts the notion that human beings are inherently flawed. Unlike these films, however, GATTACA does not question the morality of hereditary intervention to remove imperfection. Instead, the film asks the audience to consider what they lose if they remove genomic flaws.

\section{Conclusions}

It is not surprising that science fiction films consistently incorporate the latest scientific discoveries and social debates about human heredity. 
What is unexpected is that each new generation of science fiction films has revived the same eugenic themes over the last 100 years. Science fiction films consistently use the same visual cues and metaphors to address social concerns about the manipulation of human heredity. From its earliest days, however, science fiction cinema's critiques of eugenics were not aimed at the movement's underlying assumptions about human heredity and its relationship to social problems. Most of these films either implicitly accept these assumptions or incorporate them into their narratives, while, at the same time, criticizing anyone who would change human heredity.

By accepting the proposition that the essence of humanity, both the good and the bad, is deeply rooted within our genome, science fiction films take a conservative stance that questions any attempts to change the elements that make us "human." Cinematic scientists often mirror real-life scientists in attributing mystical significance to our genome. ${ }^{28}$ It is exactly such spiritual claims about the human genome that fuels the anti-technology aspects of human gene manipulation in science fiction cinema: How can scientists call our genome humanity's "soul" and then commit sacrilege by manipulating a holy object?

Eugenics is about transformation, and this is why filmmakers keep coming back to eugenic themes. Cinematic attacks on eugenics are never directed at the mechanism of hereditary manipulation. The technologies on the screen, whether potion-filled test tubes, electronic devices, or the actual tools of molecular biology, are visual cues that signify genetic transformation. In science fiction cinema, however, transformations never match the eugenic dream of a superior humanity. Rather, these films feature graphic transformations in which eugenic plans turn human beings into monsters. This is in contrast to science fiction literature where recent authors accept the notion of a cybernetically and/or genomically enhanced "posthuman."29 Rather than critiquing the societal move towards genomic enhancement and questioning what makes us human, recent science fiction literature takes the opportunity to ask: What will make us posthuman?

Our struggle with the "bestial" elements of our genome has been a core visual motif in science fiction films from the earliest ape/human comedies to the post-Scopes trial, mad evolutionist films of the late 1920s to Forbidden Planet's "monsters of the Id" all the way to the latest adaptations of The Island of Dr. Moreau. The quality of the makeup effects may significantly differ between the big studio-produced Island of Lost Souls and the B-movie, She Demons, but the visual symbolism is identical. A parallel belief in the perfectibility of the human genome 
can also be found in eugenic depictions throughout the history of cinema. While "perfection" is achievable in science fiction films from Homunculus to GATTACA, these films portray perfection as undesirable and depict a need for genomic imperfection. Homunculus's dark style of dress, his emotionless demeanor, and the film's antiseptic sets convey the same sense of spiritual deficiency as the genomically-enhanced characters and stainless steel sets in GATTACA. According to science fiction cinema, the Devil may be in our DNA, but he is our Devil, and we resent any attempt to remove him.

\section{Notes}

1. Much of the framework on the history of eugenics is taken from Kevles, In the Name of Eugenics.

2. Stock, Redesigning Humans, 2.

3. Many of the films in this essay span the boundary between science fiction and horror genres. However, my concern is with narrative themes in science-based cinema and not genre distinctions, which ultimately have little bearing on my arguments. Excellent discussions of science fiction as a genre can be found in Sobchack, Screening Space, Telotte, Science Fiction Film, and Vieth, Screening Science. It is also important to note that films in this essay relate solely to the issue of eugenics and human gene-manipulating technologies. My discussion does not include the issue of human cloning, which has its own unique history in science fiction film, except as it relates to eugenics.

4. Pernick, The Black Stork.

5. The number of films highlighting humanity's link to primates during early cinema is considerable. A partial list of films with this theme includes The Monkey Man (1908), The Apish Trick (1909), The Doctor's Experiment: or Reversing Darwin's Theory (1908), The Human Ape: or Darwin's Triumph (1909), The Miser's Conversion (1914), The Prehistoric Man (1924), A Scream in the Night (1919), Darwin Was Right (1924), and The Missing Link (1927).

6. See Crook, Darwinism, War and History, Chapter 5.

7. See Kevles, Chapter 11.

8. Haldane, "Daedalus." The text of Haldane's lecture can be found in Dronamraju, Haldane's Daedalus Revisited.

9. See Kirby, "Are We Not Men?"

10. "Publicity Story No. 24."

11. Weaver, "Islands Already," 64.

12. Robertson, The British Board of Censors, 59.

13. Kirby, "The Threat of Materialism in the Age of Genetics."

14. Patrick Gonder in "Like a Monstrous Jigsaw Puzzle"argues that the fears of nuclear radiation and genetic research spawned a new type of eugenic film in the 1950s and 1960s that he calls the "body rebellion" film. According to Gonder "mutinous" body parts in films such as The Brain That Wouldn't Die (1962) and X: The Man With X-Ray Eyes (1963) represent the "black" gene in 1950s and 1960s American society that must be purged from the "white" body. The amputation of these mutinous body parts "returns the body to a 'purified' state through the xenophobic excision of the offensive, dangerous element through a kind of violent therapy" (41). 
15. See Kevles, In the Name of Eugenics, Chapter 18.

16. Haraway, Simians, Cyborgs, and Women, 180.

17. Kirby, "Are We Not Men?"

18. Grant, "Looking Upward," 156.

19. See Silver, Remaking Eden. See also Silver, "Reprogenetics." Silver believes that the ability to direct genomic changes brings into question whether the use of these technologies for human gene manipulation could still be called eugenics, arguing that "reprogenetics and eugenics are fundamentally different from one another" (Silver, "Reprogenetics," 376). He believes that this "fundamental" difference resides in who controls, or seeks to control, the decisions surrounding genomic enhancement and their motivations. The "old" eugenics was in the hands of the state which enacted immigration and sterilization laws as a means of controlling the "societal gene pool," whose dilution was blamed for major social problems. With reprogenetics, Silver argues, control of genomic modification will be in the hands of individual parents whose sole motivation is to enhance their own offspring. Silver essentially sees consumerist driven genomic enhancement as a move away from eugenics.

20. See Agar, Liberal Eugenics.

21. For a review of contemporary debates over genomics and social conditions see Kirby, "Extrapolating Race in Gattaca."

22. Nelkin and Lindee, DNA Mystique, 156-7.

23. Kirby, "Are We Not Men?"

24. For an analysis of the rise of identity culture see Elliott, Better Than Well.

25. Kirby and Gaither, "Genetic Coming of Age," 265.

26. Pernick, Black Stork.

27. For a representative sample of scholarship on this film see Briggs and Kelber-Kaye, "There is No Unauthorized Breeding in Jurassic Park," Clayton, "Genome Time," Kirby, "The New Eugenics in Cinema," Kirby, "Extrapolating Race in Gattaca," and Wood, Technoscience in Contemporary American Film.

28. See Nelkin and Lindee, The DNA Mystique.

29. See Hayles, How We Became Posthuman.

\section{BIBLIOGRAPHY}

Agar, Nicholas. Liberal Eugenics: In Defence of Human Enhancement. Boston: Blackwell Publishing, 2004.

Briggs, Laura and Jodi I. Kelber-Kaye. "There is No Unauthorized Breeding in Jurassic Park: Gender and the Uses of Genetics." NWSA 12, no. 3 (2000): 92-113.

Clayton, Jay. "Genome Time." In Time and the Literary, edited by Karen Newman, Jay Clayton and Marianne Hirsch, 31-59. New York: Routledge, 2002.

Crook, Paul. Darwinism, War and History. Cambridge: Cambridge University Press, 1994.

Dronamraju, Krishna R., ed. Haldane's Daedalus Revisited. Oxford: Oxford University Press, 1995.

Elliott, Carl. Better Than Well. New York: W. W. Norton \& Company, 2004.

Gonder, Patrick. "Like a Monstrous Jigsaw Puzzle: Genetics and Race in Horror Films of the 1950s." The Velvet Light Trap 52 (2003): 33-44.

Grant, Barry. "Looking Upward: H.G. Wells, Science Fiction and the Cinema." Literature/Film Quarterly 14 (1986): 154-63.

Haldane, J.B.S. "Daedalus, or the Science of the Future." Lecture given in Cambridge, UK, February 4, 1923.

Haraway, Donna. Simians, Cyborgs, and Women: The Reinvention of Nature. New York: Routledge, 1991. 
Hayles, N. Katherine. How We Became Posthuman. Chicago: University of Chicago Press, 1999.

Kevles, Daniel J. In the Name of Eugenics: Genetics and the Uses of Human Heredity. New York: Knopf, 1985.

Kirby, David A. "The New Eugenics in Cinema: Genetic Determinism and Gene Therapy in GATTACA." Science Fiction Studies 27, no. 2 (2000): 193-215. . "Are We Not Men?: The Horror of Eugenics in The Island of Dr. Moreau." Paradoxa 17 (2002): 93-108.

. "The Threat of Materialism in the Age of Genetics: DNA at the Drive-In." In Horror at the Drive-In: Essays in Popular Americana, edited by Gary D. Rhodes, 241-58. Jefferson, NC: McFarland and Co., 2003.

—. "Extrapolating Race in Gattaca: Genetic Passing, Identity, the New Eugenics, and the Science of Race." Literature and Medicine 23, no. 1 (2004): 184-200.

Kirby, David A. and Laura A. Gaither. "Genetic Coming of Age: Genomics, Enhancement, and Identity in Film." New Literary History 36, no. 2 (2005): 263-82.

Nelkin, Dorothy and M. Susan Lindee. The DNA Mystique. New York: W.H. Freeman and Co., 1995.

Pernick, Martin. The Black Stork: Eugenics and the Death of "Defective" Babies in American Medicine and Motion Pictures Since 1915. Oxford: Oxford University Press, 1996.

Publicity Story No.24 for The Island of Lost Souls. "Scientist Friend Observes Wells' Adventure Filmed." Los Angeles: Paramount Studios, 1932.

Robertson, James C. The British Board of Censors: Film Censorship in Britain, 1896-1950. London: Croom Helm, 1985.

Silver, Lee. Remaking Eden: How Genetic Engineering and Cloning Will Transform the American Family. New York: Avon Books, 1998. . "Reprogenetics: Third Millennium Speculation." EMBO Reports 11, no. 51 (2000): 375-78.

Sobchack, Vivian. Screening Space: The American Science Fiction Film. New Brunswick, N.J.: Rutgers University Press, 1997.

Stock, Gregory. Redesigning Humans: Choosing Our Children's Genes. London: Profile Books, 2002.

Telotte, J.P. Science Fiction Film. Cambridge: Cambridge University Press, 2001.

Vieth, Errol. Screening Science: Contexts, Texts and Science in Fifties Science Fiction Film. Lanham, MD: Scarecrow Press, 2001.

Weaver, Tom. "Islands Already." In The Island of Dr. Moreau Official Movie Magazine, 60-66. New York: Starlog, 1996.

Wood, Aylish. Technoscience in Contemporary American Film. Vancouver, B.C.: University of British Columbia Press, 2002. 